\title{
IAMJ
}

INTERNATIONAL AYURVEDIC MEDICAL JOURNAL

\section{ROLE OF BHRAMARI PRANAYAMA IN PREVENTION AND PROMOTION OF MENTAL HEALTH - A REVIEW}

\author{
Pranita K Shinde , Kalpana Jadhao², Pradnya Shinde ${ }^{3}$, Milind M Godbole ${ }^{4}$ \\ ${ }^{1}$ Assistant Professor, Swasthavritta Department, Vidarbha Ayurved College, Amravati, Maharashtra, India \\ ${ }^{2}$ Associate Professor, Swasthavritta Department, Yashwant Ayurved College, Kodoli, Kolhapur, Maharashtra, India \\ ${ }^{3}$ Associate Professor \& HOD, Kriyasharir Department, Vidarbha Ayurved College, Amravati, Maharashtra, India \\ ${ }^{4}$ Professor and Principal, Yashwant Ayurved College, Kodoli, Kolhapur, Maharashtra, India
}

Email: dr.pranita27@gmail.com

\section{https://doi.org/10.46607/iamj0807152020}

(Published online: July 2020)

Open Access

(c) International Ayurvedic Medical Journal, India 2020

Article Received: 17/06/2020 - Peer Reviewed: 21/06/2020 - Accepted for Publication: 01/07/2020

Check for updates

\section{ABSTRACT}

Background -In today's era lifestyle of people has become very mechanical. Everyone is running in a rat race for target achievement, which results in stress. This stress further effects on physical as well as mental health of an individual. Mental health is the balanced development of emotional attitudes and personality which live harmoniously with all society or community. Mental disorders are characterized by alternation in thinking, mood or behaviour associate with impaired functioning. Mental and behavioural disorders are found in all age groups, and the prevalence rate is about $10 \%$. To overcome these problems, everyone should concentrate on prevention and promotion of health. For physical health healthy diet, daily regimen, seasonal regimen \& exercise etc. are the preventive major, and for prevention of mental health Sadvrittapalan, application of Acharrasayana, yoga \& meditation practises are essential. Yoga consists of eight processes, in this Pranayam is very important to achieve control on Indriyas that is sense organs. Bhramari Pranayam is one of significant type of Ashtakumbhaka \& very easy to practice. Vibrations produced due to humming sound of Bhramari Pranayam affects directly on the hypothalamus of the brain, causing a resonance in mind which relieves stress and produces calmness and happiness in the whole body. This article deals with the role of Bhramari Pranayama in prevention and promotion of mental health to provide a better solution. Aim - To study the role of Bhramari Pranayama in prevention and promotion of mental health. 
Setting \& Design - Literary study. Material \& Methods - The present investigation is based on primary \& secondary sources of data mainly collected from literature studies of various Ayurvedic Samhitas \& texts as well as numerous published research articles. Results \& Conclusions This study illustrates that Bhramari Pranayama plays an important role in prevention of mental health as well as curative effects on mental disorders like stress, anxiety depression. According to Ayurveda, regular practice of Bhramari Pranayama decreases the Raja and Tamadosha and increases Satvaguna, which further helps to build mental health. There is a considerable scope to study the effect of Bhramari Pranayam through clinical trials to develop the present study.

Keywords: Bhramari pranayam, prevention \& promotion, Mental health.

\section{INTRODUCTION}

The WHO stress that mental health is "more than just the absence of mental disorders or disabilities." Peak mental health is about not only avoiding existing conditions but also looking after ongoing wellness and happiness. Mental health is an active state of internal equilibrium. Mental health indicates cognitive, emotional and behavioural well-being-mental health influence on daily routine, relationships as well as physical health. Maharishi Patanjali has advocated Ashtangyoga for curative as well as preventive aspects for all physical and mental disorders. Out of these eight, Bhramari Pranayam is more effective exercise for the brain due to its humming sound, vibration is produced which affects the hypothalamus of the brain directly causing a resonance in mind, and it fills the whole body with calmness and happiness. Thus, Bhramari Pranayam helps to improve our mental health. There are many studies on the effect of Bhramari Pranayam on various systems, but there are only a few studies present on stress, anxiety, depression and other mental disorders.

Material \& Methods- The present investigation is based on primary \& secondary sources of data mainly collected from literature studies of various Ayurvedic samhitas \& Yoga texts as well as numerous published research articles.

\section{Review of Health \& Mental Health as per Ayurveda \& Modern Science:}

As per WHO, health is defined as a state of complete physical, mental, social and spiritual well-being and not merely the absence of disease or infirmity. A sound mind in a sound body has been recognized as a social, ideal for many centuries. Further WHO described Mental health as, "It is a state of well-being in which an individual realizes his or her abilities, can cope with the normal stresses of life, can work productively, and can make a contribution to his or her community."(1)

Ayurveda explained health as a - Samadosha, samagnichha, Samdhatumalakriya, Prasannatemendriya Manah, Swasthaettebhiyate. Su su15 $\backslash 41$. According to Sushruta, man is said to be Swastha whose Doshas, Agnis, Dhatus, and malas in the state of equilibrium along with mental, sensory, and spiritual pleasantness and happiness. Physiological variations of Doshas occur as daily, seasonal, age, food. Jatharagni and Bhutagni are responsible for proper digestion of food. Dhatvagnis are accountable for the nourishment of dhatus, equilibrium state of Agni leads to the appropriate formation of body tissue, and disorder of Agni leads to different diseases. Equilibrium state Dhatus and Mala is essential for the maintenance of health and prevention of diseases. A pleasant state of the soul, sense organs and mind are defined as health. Atama means Jivatma or Karma Purusuh who experiences all feelings like pleasure, pain etc. Even though the soul is devoid of blemishes as he is in association with the body, he experiences good and bad effects. Suppression of mental urges like desire, hatred, greediness, passion, following principals of Sadvritta, Achararasayana and Yoga help to keep the mind healthy. Thus, one can prevent psychological, somatic and psychosomatic disorders. $^{(2)}$

Veekaro dhatoo vaishyamyam samyam, prakrutee, vruchyatey! Sukhyasadhnyakum Arogyam, Veekaro, Dukhmevachya! (CS 9/4) Abnormal state of dhatus, which 
produces unhappiness is a disease, and a balanced state which provides happiness is Prakriti or Health, i.e. Arogya. Thus, to prevent mental health diseases, one should adopt daily seasonal regimens, proper diet, Yoga, Pranayama and meditation. Suppression of psychological urges like desire, hatred, greediness, passion, following principles of Sadvritta, Acharrasayan and Pranayam helps to keep the mind healthy. Applying these, one can prevent psychological, bodily and psychometric disorders ${ }^{(3)}$ Avidya, Asmita, Raga, Dvesha, Abhinivesha are the five "Klesha" ${ }^{4]}$ factors which can cause trouble in our day to day life. For diminishing these Kleshas, we should try to moderate the emotions in our daily life. These Kleshas constitute particular behaviour or mental state of that individual, such as aggressiveness, irritability, and rebelling nature. This type of personality has an inbuilt habit of developing stress, anxiety, and depression. The cultivation of Satvik character, i.e., pure, noble, and honest, and selfless attitude, is the need of the hour for ideal mental health. Maharshi Patanjali has advocated four essential things to be observed viz. Friendship, compassion, joy, and forgiveness. Abhyasa and vairagya are also vital to deal with stressors ${ }^{[5]}$. Pranayama has been assigned a vital role in Asthanga Yoga and is very beneficial for keeping sound mental health. Out of these eight Pranayamas, Bhramari Pranayama brings stability, calm the mind, and improves blood circulation, effective for insomnia, instant way to relieve tension, anger, anxiety. Bhramari helps in increasing the concentration of the brain by humming sound, which is produced during the breathing, gives more interest to the subject for the practice in the Pranayama. ${ }^{[6 .]}$ Mental and behavioural disorders are found in people of all regions and all age groups. In India, as per the survey of mental health, the morbidity rate is $18-20$ per thousand populations ${ }^{[7]}$. Thus, the present study was carried out for the effect of Bhramari Pranayama on mental health. Current therapies available for the management of mental diseases are valid, but the problem of tolerance and physical dependence on their prolonged use, lots of side effects may occur. Therefore, the drugless and time effective Bhramari Pranayama is beneficial to reduce the symptoms of mental diseases. In Ayurveda, the interrelation between mind and body is described in detail. The physical illness leads to disturbance in mental function, and mental disturbances lead to physical disorder ${ }^{[8]}$. While describing psychological disorder, Acharya Charaka has quoted word Chittodvega along with Kama, Krodha, Moha. It is a more applicable term to illustrate the whole mental state. ${ }^{[9]}$ Therefore, Chittodvega is included in Manasroga and compared with a mental disorder. In this review, we want to explore the relationship between the stress, anxiety and depression included as mental health

\section{Factors affecting mental health -}

Lobha, Shoka, Bhaya, Krodha, Abhimana, Nairlajja, Irsha, Atiraga, Abhidya. ${ }^{[10]}$ Not having control over Dharaniyavega is one of the reasons for Manas Roga. One whose mind is inflicted by passion, anger, greed, exhilaration, fear, confusion, exhaustion, grief, anxiety, excitement etc ${ }^{[11]}$. Antagonistic (Viruddhaahar), defective (Dushtabhojan), and contaminated food (Asuchibhojan), an insult to Gods, teachers, and Brahmnas, mental shock due to fear. are also the causes of Manasvikar-Himsa (torture), Steya (robbing), Anyathakama (unlawful sex), Paisunya (harsh speech), Anrtavacana (untruth), Sambhinnaalapa (speech causing separation), Vyapada (quarrel), Abhidya (jealousy), Drgviparyaya (misunderstanding). ${ }^{[12]}$ Always follow dashvidhapapkarma is one more cause for manas vikar. Not following Dincharya, Ratricharya, Rutucharya, Sadvritta, Achar rasayan Aharvidhivisheshayatan, Dwadashaharpravichar is a more important factor for having manas vikar.

Mental disorder according to Ayurveda- Moha (confusion), Shoka (grief), Vishada (anguish), Abhyasuya (jealousy), Irshya (envy), Bhaya (fear), Aswapna (insomnia), Chittodvega (anxiety), Tandra (stupor), Dainya (meanness of inferiority complex), Atinidra (excessive sleep), Harsha (exhilaration), Bhrama (confusion), Kama (desire), unmada (psychosis), Krodh (anger), Apasmar (epilepsy), Lobha (greed) Apatanaka patantrak, Mada (ignorance), Attatvaabhinivesh (obsessive Mana(pride) syndrome), Ashabdashravan (auditory hallucination), Madatyaya (alcoholic psychosis), Sanyasa (coma), Bhayaj and Shokajaatisara, Kamaj and Shokajjvara ${ }^{[13]}$. 
Preventive measures of mental health- Following Dincharya, Ratricharya, Rutucharya, Achar Rasayan, Sadvrittapalan by intake of Sattvikahara, Practicing Ashtangyoga (Yama, Niyam, Asan, Pranayama, Pratyahara, Dharana, Dhyana, Samadhi) ${ }^{[14]}$ Acharya has mentioned Pranayama plays a vital role to reduced Sharirik and mansikvikar.

Pranayama means a voluntary and temporary pause in the movement of the breath; it is the door between the physical existence and the spiritual path. ${ }^{[15]}$

Regular practice of Pranayama removed the covering on the light of Knowledge and mind is prepared to focus on a particular subject like Dharana. ${ }^{[16]}$

Bhramari Pranayama-Bhramari Pranayama is one of the best breathing exercises mainly for the brain. Bhramari is a Sanskrit word that is derived from 'Bhramar' the black Indian bumblebee. It describes the characteristic humming sound which is produced while exhaling. ${ }^{[17]}$

The procedure of Bhramari Pranayama-

Purvakarma- Sit in any comfortable Sukhasan position with an erect spine and stable mind, relax the body. Keep the eyes closed throughout the practice. The practice of Puraka Rechaka for ten rounds Pradhankarma. It should be practised with Shanmukhi mudra. Close the ears with the thumb, index finger on the forehead and middle fingers on eyes and ring fingers on nostrils and little fingers on above lips. Inhale (Puraka) slowly and deeply through both nostrils. Listening to the sound of the breath. After inhalation do kumbhaka, by keeping the mouth closed, Rechaka (exhale) should be done gently, making a pleasant, slow-pitch humming sound like a Bumblebee. Feel the vibration all over the body and mind. It refreshes the mood by inducing positive energy and real happiness. It is one round, and one should practice it from five rounds up to twenty rounds as per own capacity. Pachyatkarma Then do the ten rounds of Puraka \& Rechaka for Relaxation.

Matra and Kala- Practice of Puraka and Rechaka, i.e., 1:2 Matara Bhramari Pranayama Matra -Puraka 12 Matra Kumbhak Matra Rechaka 24 Matra. This is awarmatra. Kala - 4 times in a day. In morning, afternoon, evening, and midnight ${ }^{[18]}$.
Benefits of Bhramari Pranayama - While a quick force of inhalation (Puraka) one should produce high pitch humming sound like that of a male bee while doing (Rechaka) exhalation, a humming sound is produced like that of a female bee. It fills the body and mind with positive energy and real happiness. Bhramari forms vibration in the brain, and it calms the mind, relieves cerebral tension, relieves stress \& anxiety. Disparate anger, lowers blood pressure, bolsters the health of the heart, Strengthens \& improves the voice induced Sound sleep. ${ }^{(19)}$

\section{Factors affecting Mental Health as per Modern As- pect}

Childhood abuse, trauma, or neglect, social isolation or loneliness, experiencing discrimination and stigma, social disadvantage, poverty or debt, bereavement (losing someone close to you), severe or long-term stress, having a long-term physical health condition, unemployment or losing your job, homelessness or poor housing, being a long-term career for someone, drug and alcohol misuse, domestic violence, bullying or other abuse as an adult, significant trauma as an adult, such as military combat, being involved in a serious incident in which you feared for your life, or being the victim of a violent crime, physical causes - for example, a head injury or a neurological condition such as epilepsy can have an impact on your behavior and mood. Although lifestyle factors including work, diet, drugs and lack of sleep can all affect your mental health, if you experience a mental health problem, there are usually other factors as well. ${ }^{(20)}$

Warning signals of poor mental health- Always worried, poor concentration, sadness, short-tempered, regular insomnia, Wide fluctuations in mood, feelings of guilt or low self-worth, afraid without cause. Without physical cause, numerous aches and pains.

Mental Disorders According to Modern aspectsAlzheimer's disease, Dementia, delirium, harmful use of alcohol, opioid dependence syndrome, Schizophrenia, mood disorders, effective bipolar disorders, depressive episode, generalized anxiety disorder, behavioural syndrome, and physical factor, e.g. Eating disor- 
ders and sleep disorders., Mental retardation, Emotional disorders, hyperkinetic disorders, conduct disorders, unspecified mental disorders. ${ }^{(21)}$

\section{RESULTS AND DISCUSSION}

The data obtained from various texts books and review articles about the effect of Bhramari Pranayama on mental health, all studies show the curative as well as the preventive effects of Bhramari Pranayama on stress, anxiety, depression. Even though the reviews are very few, it creates a floor for further research in this field. There is a vast area unexplored on the effects of Bhramari Pranayama on mental disorder. On that aspect, [Vialattle et al. 2008] EEG studies have shown increased theta activity, and paroxysmal gamma waves following the Bhramari Pranayama bring positive thoughts and feelings of happiness ${ }^{[2]}$. The regular practice of Bhramari Pranayama increased parasympathetic tone, decreases sympathetic activity, and improves cardiovascular and respiratory functions, reduced the effect of stress and strain on the body and improves mental and physical health.[Bhargava et el 1998, Thangavel et el2014] ${ }^{[23]}$ Previously studies [Jain et el 2011 and Rampalliwar et el 2013] have mentioned that Bhramari Pranayama also reduces cardiovascular reactivity to stress[ cold pressure test] by inducing parasympathetic predominance and cortico- hypothalamic medullary inhibition ${ }^{[24]}$. [Diwakar pal et el 2016] found that the experimental group[doing [Bhramari Pranayama] improved to reduce anxiety levels than the controlled group ${ }^{[25]}$. [ Shrivastav et el 2016] have mentioned that Bhramari Pranayama stimulates the reflex of the Autonomic nervous system and, in turn, the level of noradrenaline and neurotransmitters in the nervous system increase with a deeper breath and resonate while exhaling. This secreted noradrenalin helps to decrease the level of neurohormones responsible for stress, anxiety, and aroused mental state in deeper form through biofeedback mechanism. ${ }^{[26]}$

\section{CONCLUSION}

Acharya Charak stated that Raja and Tama are the chief pathogenic factors of mind, and due to them, a lot of manas vikar are produced. The regular practice of
Bhramari Pranayama decreases the Raja and Tamadosha and increases Satwaguna. From the above discussion, it is concluded that the daily practice of Bhramari Pranayama produces acoustic vibrations, and this vibration could have a significant impact on brain tissues. It is an excellent stretching exercise by one's voice. It influences multiple systems in the body like respiratory, autonomic nervous systems; hence its effects on total emotional status as well as mental disorders like stress, anxiety, and depression. Thus, more clinical trials are essential to study the effect of Bhramari Pranayama on mental health. Therefore, Bhramari Pranayama is a crucial part of our daily stressful life for preventive as well as curative aspects for mental health.

\section{REFERENCES}

1. K. Park Preventive \& Social Medicine .23rd edition 2005, page number 831,832 .

2. Dr. Anantaram Sharma Sushrut Samhita Vol. 1, Choukhambha Surbharti Prakashan, editor, Reprinted

3. ed., 2009, pp. 130 Sutrasthan, dosh dhatu mal kshaya vrudhi vidyananiya adhyay $15 / 41$.

4. Brahmanand Tripathi, Charak Samhita, Vol.1, Choukhambha Surbharti Pratishthan, editor, Reprinted ed.2006 Chikitsasthan 9/4.

5. Swami Hariharananda Aarnya, Patanjal Yoga darshanam, Motilal Banarsidas, editor,1980, samadhiapad , 03

6. Swami Hariharananda Aarnya, Patanjal Yoga darshanam, Motilal Banarsidas editor,1980, samadhiapad , 12

7. Kuppusamy Maheshkumar, Dilara Kamaldeen, Ravishankar Pitani and Julius Amaldas, "Immediate Effects of Bhramari Pranayama on Resting Cardiovascular Parameters in Healthy Adolescents", Journal of Clinical and Diagnostic Research.Vol-10(5), :17-19, 2016

8. K. Park Preventive \& Social Medicine. 23rd edition 2005, page number 831,832

9. Dr. Anantaram Sharma, Sushrut Samhita, vol.1, Choukhambha Surbharti Prakashaneditor, Reprinted ed. 2009 pp. 3 sutrasthan, vedotpattirdhya $1 / 3$.

10. Brahmanand Tripathi, Charak Samhita, Vol.1, Choukhambha Surbharti Pratishthan, editor, Reprinted ed.2006 pp. 596 Viman Sthan, Roganikviman adhyaya6/5. 
11. Brahmanand Tripathi, Charak Samhita, Vol.1, Choukhambha Surbharti Pratishthan, editor, Reprinted ed.2006 Sutrasthan 7/26,27

12. Brahmanand Tripathi, CharakSamhita, Vol.1, Choukhambha Surbharti Pratishthan, editor, Reprinted ed.2006 Nidansthan 7/4.

13. Kaviraj Atridev Gupta, Ashtang Hridaya Choukhambha Prakashan editor, Reprinted 2008 Sutrasthan 2/21-22.

14. https://www.researchgate.net.

15. Swami Hariharananda Aarnya Patanjal Yoga Darshanam, Motilal Banarsidas editor,1980, pp. 282-283 sadhanapad, 2-29.

16. Swami Hariharananda Aarnya Patanjal YogaDarshanam, Motila 1Banarsidas editor, 1980, pp. 282-283 sadhanapad, 2/49.

17. Swami Hariharananda Aarnya Patanjal Yoga Darshanam, Motilal Banarsidas editor,1980, pp. 282-283 sadhanapad, 2/52-53.

18. Swami Muktibodhananda, Hathyoga Pradipika,-Light on Hatha Yoga", Yoga Publication Trust ,Munger ,Bihar Edt.3rd -1998,Reprinted 2006 pp.260Shatkarma and pranayama, 2/68.

19. Hatha Yoga Pradipika- Swami Muktibodhanand light on Hatha Yoga Bihar School of Yoga Pg. No. 173 Sh.No. 11.

20. Banyan botanicals

21. www.medicalnewstoday.com/depression

22. K Park Preventive \& Social Medicine K.Park 23rd edition 2005 , page number 831,832

23. Vialatte, F. B., Bakardjian, H., Prasad, R., \&Cichocki, A. (2009). EEG paroxysmal gamma waves during Bhramari Pranayama: a yoga breathing technique. Consciousness and cognition, 18(4), 977-988

24. Bhargava R, Gogate MG, Mascarenhas JF. Autonomic responses to breath holding and its variations following pranayama. Indian J Physiol Pharmacol 1988; 32:25764.

25. Jain, G., C. Rajak, and S. Rampalliwar. "Effect of bhramari pranayama on volunteers having cardiovascular hyper-reactivity to cold pressor test." J Yoga Phys Ther 1 (2011): 102

26. Pal Diwakar. "Effect of Bhramari Pranayama on the state of anxiety on sedentary male from Gwalior.

\section{Source of Support: Nil \\ Conflict of Interest: None Declared}

How to cite this URL: Pranita K Shinde et al: Role Of Bhramari Pranayama In Prevention And Promotion Of Mental Health A Review. International Ayurvedic Medical Journal \{online\} 2020 \{cited July, 2020\} Available from: http://www.iamj.in/posts/images/upload/3913 3918.pdf 